Volume: 07, Issue: 05 "September-October 2021"

\title{
EFFECTS OF SOME FOOD DYES AND SEVERAL PLANT EXTRACTS ON SURVIVAL PERCENTAGE IN DROSOPHILA MELANOGASTER (MWH X FLR)
}

\author{
Aylin YILMAZ ÇETINNKAYA \\ Keşan Hakkı Yörük School of Health, Turkey Trakya University, Turkey \\ ORCiD: 0000-0001-6807-9016 \\ DOI: https://doi.org/10.51193/IJAER.2021.7505
}

Received: 23 Oct. 2021 / Accepted: 30 Oct. 2021 / Published: 05 Nov. 2021

\begin{abstract}
In this study, effects of different concentrations $(25 \mathrm{~g} / \mathrm{L}, 50 \mathrm{~g} / \mathrm{L}$ and $75 \mathrm{~g} / \mathrm{L})$ of three food dyes (Ponceau 4R, Tartrazine and Pea green) used in food industry and $100 \mathrm{~g} / \mathrm{L}$ concentration of several plant extracts, namely (Hypericum perforatum L., Silybum marianum (L.) Gaertn., Lavandula stoechas L.), stated to have anti-toxic agents in many sources, were investigated on survival percentage in the fruit fly, Drosophila melanogaster Meigen (mwh x flr). mwh $\neg-$ flr3 cross was used in the experiments. While three-day-old Drosophila larvae were chronically fed on standard Drosophila instant medium with the food dyes in experimental groups and the food dyes along with the plant extracts in treatment groups. Feeding ended with pupation of the surviving larvae. Control group was prepared with distilled water. Survival percentage of Drosophila females and males in the experimental groups, the treatment groups and control group were statistically compared by use of Chi-square test. It was observed that all concentrations of the Tartrazine in the experimental groups decreased the Drosophila melanogaster' $s$ male and female individuals life span according to control group, while the Ponceau 4R and Pea green were not succesful at it. On the other hand, when the survival percentage of the Drosophila females and males in the treatment groups of Pea green were compared with the control group, it was seen that all the plant extract had effects to increase survival rate, while the plant extracts were not effective in the treatment groups of the Ponceau $4 \mathrm{R}$ and the Pea green.
\end{abstract}

Keywords: Drosophila melanogaster Meigen ( $m w h x f l r)$, fooddyes, plant extracts, survival percentage, toxicity, anti-toxicity 
International Journal of Agriculture and Environmental Research

ISSN: 2455-6939

Volume: 07, Issue: 05 "September-October 2021"

\section{INTRODUCTION}

With the new technologies used in the food industry and the increasing variety of products, the interest in ready-made foods is increasing day-by-day with consumer demand [1] (Akbulut, 2011). Food additives are frequently found in ready-to-eat foods and are among the potentially important genotoxic agents [2, 3] (Vural, 2005; Alkan \& Anlas, 2015). In addition to the nutritional values of consumed food, its safety and effects on human health are nowadays widely discussed [3] (Alkan \& Anlas, 2015).

Food dyes can create allergic reactions, skin rashes, asthma, hyperactivity and concentration disorder, hypersensitivity, migraine, preterm delivery, salicylate sensitivity and cancer when not used within legal restrictions [4, 5] (Yentur et al., 1996; Maier et al., 2010).

With genotoxicity tests and epidemiological studies on Drosophila, mouse, rat, and bacteria, when not used within the limits specified in regulations, synthetic food dyes have been reported to be carcinogenic when used in order to imitate the high quality [4, 6] (Yentur et al., 1996; Sarikaya et al., 2010). It has been determined that the level of food dyes used in studies on this subject in our country is well above the statute limits and may have harmful effects in terms of public health [4, 7, 8] (Yentur et al., 1996; Topsoy, 1990; Yaman, 1996).

The synthetic food dyes used in the present study were preferred because, in the literature, there are very few scientific studies similar to the subject of the present research. There are few studies carried out on Drosophila regarding the toxicity of these food dyes.

In addition, the plant extracts, widely used among the public and thought to eliminate effects of cancer, used in the present study was preferred because, in the literature, there are few scientific studies on the toxicity of Hypericum perforatum L. and there is no study carried out on Silybum marianum (L.) Gaertn. and Lavandula stoechas L. in Drosophila.

The present research was conducted in order to determine whether Ponceau 4R-E124, Tartrazine-E 102, Pea green-E 102-E 133 at 25 g/L, 50 g/L, 75 g/L concentrations have negative effects on survival percentage in D. melanogaster Meigen's mwh and flr3 lines and Hypericum perforatum L., Silybum marianum (L.) Gaertn. and Lavandula stoechas L. at $100 \mathrm{~g} / \mathrm{L}$ concentration be successful in reducing the toxic effects of the food dyes or not.

\section{MATERIALS AND METHODS}

\subsection{Culture of Drosophila Lines}

D. melanogaster Meigen lines used in the present study were obtained from Trakya University and Akdeniz University, Science Faculty, Department of Biology. Fruit flies were cultured in an 
incubator where optimum living conditions $\left(25 \pm 1{ }^{\circ} \mathrm{C}\right.$ and $40-60 \%$ relative humidity) were provided and adjusted to 12 hours light and 12 hours dark time cycle.

\subsection{Genetic Structure of Drosophila Mutant Strains}

In the present study, $m w h$, flr3 and $B d S$ (beaded serrate) marker genes on the third-largest chromosome of Drosophila are used and flr3/TM3, BdS virgin females and $\mathrm{mwh} / \mathrm{mwh}$ males are crossed for normal metabolic activity [9-11] (Lindsley \& Grell 1968; Lindsley \& Zimm 1992; Garcia-Bellido \& Dapena 1974).

Experiments in the present study were simultaneously conducted in the application groups consisting of experimental, treatment and control groups. Distilled water was used in the control group. Also, all of the food dyes and the plant extracts used in the experiments dissolved in distilled water.

While Ponceau 4R, Tartrazine and Pea green were used in Drosophila larvae at $72 \pm 4$ hours and at 25\%o, 50\%o, and 75\% concentrations in the experimental group, Hypericum perforatum L., Silybum marianum (L.) Gaertn. and Lavandula stoechas L. were used at $10 \%$ concentration in treatment groups.

D. melanogaster Meigen lines were fed with a standard Drosophila instant medium when kept in stock and in a cross bottle in order to ensure the fertilization and embryogenesis to obtain heterozygous larvae. Drosophila instant medium was used in Drosophila larvae at $72 \pm 4$ hours in the experimental, treatment and control groups. Drosophila instant medium, the food dyes and the plant extracts used in the study were purchased commercially. Drosophila instant medium was procured from Carolina Biological Supply Company, Ponceau 4R and Pea green from Roha JJT Group Company, Tartrazine from Parshwanath Colour Chem Group, Hypericum perforatum L. (St. John's wort) and Silybum marianum (L.) Gaertn. (milk thistle) from Solgar, Lavandula stoechas L. (topped lavender) from Herbal Pharm.

\subsection{Applications in Experimental Groups}

Larvae in groups of 100 were left into falcon tubes, where $1.5 \mathrm{~g}$ of Drosophila instant medium were wetted with $5 \mathrm{ml}$ of solutions containing 25\%, 50\%o and 75\%o concentrations of Ponceau 4R, Tartrazine and Pea green and/or 10\% concentration of the plant extracts. Larvae were placed on standard medium containing chemicals to complete their development. Adult fruit flies emerging from the pupa were stunned with ether. The flies were counted by discriminating between males and females.

\subsection{Statistical Analysis}


Volume: 07, Issue: 05 "September-October 2021"

In the data analysis, Chi-Square test was used to determine whether there was a significant difference between the experiment groups, the treatment groups and the control group in terms of Drosophila's female and male individuals survival. Data analyzed with the SPSS (Ver.22) Package Program.

\section{RESULTS}

Survival percentage results of the experimental groups consisting of the three food dyes at the different concentrations, the treatment groups including the several plant extracts at the one concentration and the control group were given in turn; in Table 1, 2 and 3.

Table 1: Effects of Ponceau 4R and Hypericum perforatum L., Silybum marianum (L.) Gaertn., Lavandula stoechas L.) on survival percentage in Drosophila melanogaster (mwh $\mathbf{x}$ flr)

\begin{tabular}{|c|c|c|}
\hline $\begin{array}{l}\text { Application groups/ } \\
\text { Concentration (g/L) }\end{array}$ & $\begin{array}{c}\text { Numbers ofDrosphila } \\
\text { female }\end{array}$ & $\begin{array}{c}\text { Numbers ofDrosphila } \\
\text { male }^{\mathrm{X}^{2}}\end{array}$ \\
\hline Distilled water & 46 & 52 \\
\hline 25 Ponceau 4R & 30 & 28 \\
\hline 50Ponceau 4R & 29 & 33 \\
\hline 75 Ponceau 4R & 31 & 27 \\
\hline 25 Ponceau 4R-H. perforatum & 34 & 28 \\
\hline 25 Ponceau 4R-S. marianum & 34 & 30 \\
\hline 25 Ponceau 4R-L. stoechas & 40 & 37 \\
\hline 50 Ponceau 4R-H. perforatum & 22 & 32 \\
\hline 50 Ponceau 4R-S. marianum & 32 & 37 \\
\hline 50 Ponceau 4R-L. stoechas & 30 & 32 \\
\hline 75 Ponceau 4R-H. perforatum & 24 & 25 \\
\hline 75 Ponceau 4R-S. marianum & 47 & 28 \\
\hline 75 Ponceau 4R-L. stoechas & 35 & 20 \\
\hline
\end{tabular}

$\mathrm{X}^{2}$ : In evaluation with Chi-Square test; a: with Distilled water, *: $\mathrm{P}<0.05$ 
Table 2: Effects of Tartrazine and Hypericum perforatum L., Silybum marianum (L.) Gaertn., Lavandula stoechas L.) on survival percentage in Drosophila melanogaster (mwh $\mathbf{x}$ flr)

\begin{tabular}{|c|c|c|}
\hline $\begin{array}{l}\text { Application groups/ } \\
\text { Concentration (g/L) }\end{array}$ & $\begin{array}{c}\text { Numbers of Drosphila } \\
\text { female } X^{2}\end{array}$ & $\begin{array}{c}\text { Numbers of Drosphila } \\
\text { male } \mathrm{X}^{2}\end{array}$ \\
\hline Distilled water & 46 & 52 \\
\hline 25 Tartrazine & $32 a^{*}$ & $22 a^{*}$ \\
\hline 50 Tartrazine & $37 a^{*}$ & $15 \mathrm{a}^{*}$ \\
\hline 75 Tartrazine & $16 a^{*}$ & $22 a^{*}$ \\
\hline 25 Tartrazine-H. perforatum & 28 & 26 \\
\hline 25 Tartrazine-S. marianum & 32 & 31 \\
\hline 25 Tartrazine-L. stoechas & 45 & 28 \\
\hline 50 Tartrazine-H. perforatum & 15 & 18 \\
\hline 50 Tartrazine-S. marianum & 34 & 32 \\
\hline 50 Tartrazine-L. stoechas & 34 & 34 \\
\hline 75 Tartrazine-H. perforatum & 36 & 37 \\
\hline 75 Tartrazine-S. marianum & 31 & 36 \\
\hline 75 Tartrazine-L. stoechas & 24 & 46 \\
\hline
\end{tabular}

$\mathrm{X}^{2}$ : In evaluation with Chi-Square test; a: with Distilled water, *: $\mathrm{P}<0.05$

Table 3: Effects of Pea green and Hypericum perforatum L., Silybum marianum (L.) Gaertn., Lavandula stoechas L.) on survival percentage in Drosophila melanogaster (mwh $\mathbf{x}$ flr)

\begin{tabular}{|l|c|c|}
\hline \multicolumn{1}{|c|}{$\begin{array}{c}\text { Application groups/ } \\
\text { Concentration (g/L) }\end{array}$} & $\begin{array}{c}\text { Numbers ofDrosphila } \\
\text { female }^{\mathrm{X}^{2}}\end{array}$ & $\begin{array}{c}\text { Numbers ofDrosphila } \\
\text { male }^{\mathrm{X}^{2}}\end{array}$ \\
\hline Distilled water & 46 & 52 \\
\hline 25 Pea green & 37 & 32 \\
\hline 50 Pea green & 37 & 32 \\
\hline 75 Pea green & 38 & $36 \mathrm{a}^{*}$ \\
\hline 25 Pea green-H. perforatum & $25 \mathrm{a}^{*}$ & 25 \\
\hline
\end{tabular}


International Journal of Agriculture and Environmental Research

ISSN: 2455-6939

Volume: 07, Issue: 05 "September-October 2021"

\begin{tabular}{|l|l|l|}
\hline 25 Pea green-S. marianum & $32 \mathrm{a}^{*}$ & $36 \mathrm{a}^{*}$ \\
\hline 25 Pea green-L. stoechas & $34 \mathrm{a}^{*}$ & $28 \mathrm{a}^{*}$ \\
\hline 50 Pea green-H. perforatum & $18 \mathrm{a}^{*}$ & $31 \mathrm{a}^{*}$ \\
\hline 50 Pea green-S. marianum & $33 \mathrm{a}^{*}$ & $32 \mathrm{a}^{*}$ \\
\hline 50 Pea green-L. stoechas & $31 \mathrm{a}^{*}$ & $36 \mathrm{a}^{*}$ \\
\hline 75 Pea green-H. perforatum & $13 \mathrm{a}^{*}$ & $29 \mathrm{a}^{*}$ \\
\hline 75 Pea green-S. marianum & $40 \mathrm{a}^{*}$ & $19 \mathrm{a}^{*}$ \\
\hline 75 Pea green-L. stoechas & $27 \mathrm{a}^{*}$ & $20 *$ \\
\hline
\end{tabular}

$\mathrm{X}^{2}$ : In evaluation with Chi-Square test; a: with Distilled water, *: $\mathrm{P}<0.05$

In this study, the effects of the three food dyes (Ponceau 4R, Tartrazine and Pea green) at different concentrations (25 g/L, $50 \mathrm{~g} / \mathrm{L}$ and $75 \mathrm{~g} / \mathrm{L}$ ) and several plant extracts (Hypericum perforatum L., Silybum marianum (L.) Gaertn., Lavandula stoechas L.) at $100 \mathrm{~g} / \mathrm{L}$ concentration were investigated on survival rate in Drosophila melanogaster ( $m w h \quad x$ flr). Different concentrations of the food dyes and $100 \mathrm{~g} / \mathrm{L}$ concentration of the several plant extractswere examined and survival percentages determined in Drosophila larvae. Whether there is a difference between the experimental groups in terms of survival rates was calculated with ChiSquare test.

Survival percentages in Drosophila's female and male flies in the experimental groups of Tartrazine decreased significantly at all concentrations compared to the control group. The data indicated that in Table 2; toxic effect of the Tartrazine increased in a dose-dependent manner in all experimental groups. In terms of their toxicity, the food dyes sorted as; Tartrazine>Ponceau 4R and Pea green.

On the other hand, when the present study data on life span in Drosophila females and male in the treatment groups of Pea green were compared with the control group, it was seen that results were statistically significant in Table 3. However, the three plant extracts did not affect surviving of fruit flies in the treatment groups of the other food dyes. As a result, the plant extracts did not have anti-toxic effects against the food dyes in the study.

\section{DISCUSSION}

The data are not similar in toxicity to the following studies on Ponceau 4R. Uysal \& Semerdoken [12] showed increased toxicity in Drosophila larvae at $72 \pm 4$ hours due to the concentration increase of Ponceau 4R, Semerdoken [13] reported that it showed an increase in mortality rate of Oregon R wild and Vestigial mutant strains of Drosophila larvae ( $72 \pm 4$ hours) as the application 
International Journal of Agriculture and Environmental Research

ISSN: 2455-6939

Volume: 07, Issue: 05 "September-October 2021"

concentration of Ponceau 4R rise, Turkoglu et al. [14] published that the longevity in Drosophila melanogaster decreased significantly, depending on the different concentrations of Ponceau $4 \mathrm{R}$ and Uysal et al. [15] notified that maximum mean life of Oregon $\mathrm{R}$ wild of D. melanogaster larvae at $72 \pm 4$ hours decreased in different concentrations of Ponceau $4 \mathrm{R}$ depend on feeding. The researches data are not compatible and supports the results of this study.

The data obtained in the present study, which clearly show the toxicity of Tartrazine, are supported by the following researches on toxic effect of this food dye reported in the literature. Semerdoken [13] issued that Tartrazine increased the mortality rate in Oregon R wild and Vestigial mutant strains of Drosophila larvae at $72 \pm 4$ hours, Uysal et al.[15]reported that, according to larval mortality and life span, Tartrazine had the highest toxicity in Oregon R wild of D. melanogaster larvae at $72 \pm 4$ hours among other food dyes, Tripathy et al.[16] reported that Tartrazine had genotoxicity in Drosophila melanogaster Meigen at $0.6 \%$ and $1.2 \%$ concentrations using the eye mosaic test and the wing spot test, Çetinkaya \& Yurtsever [17] reported that Tartrazine had genotoxic effect in Drosophila melanogaster Meigen at 25\%, 50\%o and $75 \%$ concentrations using somatic mutation and recombination test (SMART) and Çetinkaya \& Yurtsever [18], in their study about investigating the genotoxicity of Tatrazine in Drosophila melanogaster and the anti-genotoxicity of some plant extracts using the SMART test, concluded that Tartrazine was a genotoxic agent.

The present study result is partially consistent with the researches below, where examining the toxic effects of Pea green (Tartrazine-E 102 and Brilliant Blue FCF-E 133 combination) are examined. Uysal \& Semerdoken [12] reported increased toxicity in Oregon R of Drosophila larvae (72 \pm 4 hours) depending on the increase in concentration of Pea green, Turkoglu et al. [14] notified that Brilliant Blue FCF caused the biggest decreased on life span in Drosophila melanogaster among other food dyes, Kumar et al. [19] revealed that on exposure to Brilliant Blue, Drosophila melanogaster larvae and pre-adult stages were prone to developmental toxicity, El-keredy [20] concluded that different concentrations of Tartrazine increased the rate of toxicity and disruption of sexual ratio in Drosophila melanogaster. Wusu et al. [21] (2020) reported that since Tartrazine could induce apoptosis in D. melanogaster larvae at $72 \pm 4$ hours and it was a risk factor in developmental toxicity.

Hypericum perforatum L., Silybum marianum (L.) Gaertn. and Lavandula stoechas L. did not show positive effects on survival percentages caused by Ponceau 4R, Tartrazine and Pea green in Drosophila.

When the literature is examined, it is seen that there are a few studies about anti-toxicity of these plant extracts in D. Melanogaster Meigen. It was also given below that similar anti-toxicity studies in various model organisms about the plant extracts evaluated with different test systems. 
International Journal of Agriculture and Environmental Research

ISSN: $2455-6939$

Volume: 07, Issue: 05 "September-October 2021"

Neo et al.[22] reported that $H$. perforatum L. at 2.5\%, $12.5 \%$ and $50 \%$ concentrations slowed cell death in Drosophila cells suppressing the expression of denatured proteins, Uysal et al.[23] showed that $H$. perforatum $\mathrm{L}$. at different concentrations did not cause elongation in $D$. Melanogaster Meigen F1 progeny transformation time to adult, increased numbers of offspring due to increase at concentrations and had highest numbers of offspring at $10 \mathrm{ml} / 100 \mathrm{ml}$ concentration, Branda et al.[24] published that $H$. perforatum L. taken with diet was ineffective on leukopenia caused by chemotheropathic drugs on experimental cancer model induced in rats and Martarelli et al.[25] notified that while $H$. perforatum L. prepared in methanol at $80 \%$ concentration reduced rate of growth and development of prostate adenocarcinoma cells in humans, experimental cancer induced in mice at $70 \%$ concentration.

Can [26] reported that S. marianum (L.) Gaertn. taken with diet at $10 \%$ concentration reduced DNA damage and apoptosis in rats with liver damage induced by carbon tetrachloride, Zhou et al. [27] showed that active substances of S. marianum (L.) Gaertn. was effective reducing DNA damage and regulation of cell cycle in rats and Garcia-Maceira \& Mateo [28] published that cervical and liver cancers in humans are inhibited by S. Marianum (L.) Gaertn.

Kulcanay [29] notified that when oil with leaf and flower extracts of Lavandula stoechas ssp. Stoechas evaluated with Salmonella/microsome test, they were mutagenic, Ayral [30] reported that while some of essential oil compounds in above ground parts of Lavandula stoechas L. had strong cytotoxic and anti-bacterial effects in different cancer cells, Margo et al., [31] showed that when one of the anti-genotoxic effects of Lavandula stoechas L. tested for fungistatic (delaying or inhibiting fungal growth) activity in various mushrooms, the plant extract was ineffective.

Results of the researches above mentioned and these study data are not parallel to each other. Accordingly, the study data show that these plant extracts were ineffective at $100 \mathrm{~g} / \mathrm{L}$ concentration studied as a single dose in protecting fruit flies against the toxicity of the synthetic food dyes. More basic and clinical studies are need to be determined for effectiveness of the plant extracts. Furthermore, the plant extracts can be used in different concentrations and for longer periods of time. Determining the efficacy and safety of the plant extracts is closely related to the health of today and in the future generations.

It is thought that this study can contribute to scientific researches and similar experiments will do later. More scientific studies are required to explain molecular mechanisms and distributions of the toxicity of the food dyes and the anti-toxicity of the plant extracts by using in vivo and in vitro test systems in/on different model organisms.

Nutrition is one of the most important factors ensuring the continuity of life. Nowadays, it is seen that people's eating habits significantly differ as a result of the changes in lifestyle and economic 
International Journal of Agriculture and Environmental Research

ISSN: 2455-6939

Volume: 07, Issue: 05 "September-October 2021"

development[1]. With controlling the synthetic food dyes and the plants extracts consumption public health should be protected.

\section{REFERENCES}

[1] AKBULUT, M. Food additives: functions and resources. in 1.Ulusal Helal ve Sağglkll Glda Kongresi. 2011.

[2] Vural, N., General Toxicology. Anadolu Üniversitesi Eczacılık Fakültesi Yayınları. 2005.

[3] Alkan, F. and C. Anlas, Genotoxicity tests and genotoxic poisons. Turkish Clinics J Vet Sci Pharmacol Toxicol-Special Topics, 2015. 1: p. 69-74. https://doi.org/10.1016/S0959$\underline{437 X(00) 00190-8}$

[4] Yentür, G., Investigation of the amount of synthetic dye in cake decorations and some candies provided from Ankara market. Ankara Üniversitesi Veteriner Fakültesi Dergisi, 1996. 43(4): p. 479-484.

[5] Maier, E., et al., Food preservatives sodium benzoate and propionic acid and colorant curcumin suppress Thl-type immune response in vitro. Food and chemical toxicology, 2010. 48(7): p. 1950-1956.https://doi.org/10.1002/bies.950150612

[6] Sarıaya, R., Selvi, M , Akkaya, N , Acar, M , Erkoç, F ., Farklı Konsantrasyonlardaki Glda Boyalarının Drosophila melanogaster ( $m w h x$ flr)'de Yaşama Yüzdesi Üzerine Etkisi. Süleyman Demirel Üniversitesi Fen Edebiyat Fakültesi Fen Dergisi, 2010. 5(1): p. 38-46.

[7] Topsoy, H., Quantification of synthetic paints added to some sugary foods. Ankara Üniversitesi Sağlık Bilimleri Enstitüsü Yayınları, 1990.

[8] Yaman, M., Investigation of synthetic dye amount added to some foodstuffs. Gazi Üniversitesi Sosyal Bilimleri Enstitüsü Yayınları, 1996.

[9] Lindsley, D.L. and E.H. Grell, Genetic variations of Drosophila melanogaster. 1968. 11: p. 12.https://doi.org/10.1126/science.162.3857.993

[10] Lindsley, D.L. and G.G. Zimm, The genome of Drosophila melanogaster. 2012: Academic press.

[11] Garcia-Bellido, A. and J. Dapena, Induction, detection and characterization of cell differentiation mutants inDrosophila. Molecular and General Genetics MGG, 1974. 128(2): p. 117-130. https://doi.org/10.1007/BF02654485

[12] Uysal H., S.S., Determination of the effects of Drosophila melanogaster on synthetic food paints on larval toxicity and adult longevity in oregon $R$ line. . Kafkas Üniversitesi Fen Bilimleri Enstitüsü Dergisi,, 2011. 4(1): p. 71-87. .

[13] Semerdoken, S., Effects of some synthetic azo food dyes added to foodstuffs on larval mortality and longevity of Drosophila melanogaster's oregon $R$ wild and vestigial mutant strains. Atatürk Üniversitesi Fen Bilimleri Enstitüsü Yayınları, 2012. 
International Journal of Agriculture and Environmental Research

ISSN: 2455-6939

Volume: 07, Issue: 05 "September-October 2021"

[14] Türkoğlu, Ş., D. Benli, and N. Şahin, The effects of five food dyes on the longevity of Drosophila melanogaster. 2015.

[15] Uysal, H., S. Genç, and A. Ayar, Toxic Effects of Chronic Feeding with Food Azo Dyes on Drosophila melanogaster Oregon R. Scientia Iranica, 2017. 24(6): p. 3081-3086. https://dx.doi.org/10.24200/sci.2017.4523

[16] Tripathy, N.K., K.K. Patnaik, and M.J. Nabi, Genotoxicity of tartrazine studied in two somatic assays of Drosophila melanogaster. Mutation Research/Genetic Toxicology, 1989. 224(4): p. 479-483. https://doi.org/10.1016/0165-1218(89)90073-6

[17] Yılmaz Çetinkaya, A. and S. Yurtsever, Somatic mutations and recombination test in Drosophila melanogaster used for investigating the genotoxicity of some food additives. International Journal of Agriculture Environment and Food Sciences, 2021. 5(1): p. 6573. https://doi.org/10.31015/jaefs.2021.1.9

[18] Yılmaz Çetinkaya, A. and S. Yurtsever, Investigation of the Genotoxicity of Tatrazine and Anti-Genotoxicity of Some Plants Extracts in Drosophila Melanogaster Using the Smart Test. Journal of Health, Medicine and Nursing, 2021. 89: p. 20-29. https://doi.org/10.7176/JHMN/89-04

[19] Parameswara Bushan Kumar, S.M., Basayya Arunkumar, Divya Shree Ramamurthy, "Effect of Developmental Toxicity in Drosophila melanogaster on Exposure to Different Food Dyes (Brilliant Blue and Sunset Yellow)". International Journal of Science and Research (IJSR), 2020. 9(12): p. 637 - 641. https://doi.org/10.21275/SR201212195534

[20] EL-KEREDY, A., Experiment on the genetic toxicity of tartrazine yellow and behavioral effects on Drosophila melanogaster. Egyptian Journal of Genetics and Cytology, 2017. 46(1): p. 33-42. https://doi.org/10.21608/ejgc.2018.9497

[21] Wusu, A.D., et al., Tartrazine increases oxidative stress and modulates the expression of apoptotic-regulatory genes in Drosophila melanogaster. Polish Journal of Natural Sciences, 2020. 35(4). https://doi.org/0000-0001-5284-588X

[22] Neo A., T.D., Ferguson A., Morris C., Investigation of the Effects of St John's Wort on Cancer and Drosophila. AOS-HCI Combined Research Paper, Hwa Chong Institution, 2011.

[23] Handan Uysal, A.A.K., Omer Faruk Algur, Rahmi Dumlupynar and Mehmet Nuri Aydogan, Recovering Effects of Aqueous Extracts of Some Selected Medical Plants on the Teratogenic Effects During the Development of D. melanogaster. . Pakistan Journal of Biological Sciences, $2007 . \quad \mathbf{1 0}(10):$ p. 1708-1712. https://doi.org/10.3923/pjbs.2007.1708.1712

[24] Branda, R.F., et al., Vitamin E but not St. John's wort mitigates leukopenia caused by cancer chemotherapy in rats. Translational Research, 2006. 148(6): p. 315-324. https://doi.org/10.1016/j.trs1.2006.05.007 
[25] Martarelli, D., et al., Hypericum perforatum methanolic extract inhibits growth of human prostatic carcinoma cell line orthotopically implanted in nude mice. Cancer Letters, 2004. 210(1): p. 27-33. https://doi.org/10.1016/j.canlet.2004.01.031

[26] CAN, M.İ., Karbon tetraklorür (CCl4) ile karaciğer hasarl oluşturulmuş ratlarda deve dikeni (Silybum marianum L.)'nin kaspaz-3, kaspaz-9, bax, BCL-2 proteinlerinin ekspresyonu ve DNA hasarl üzerine etkisi/The effect of thistle (Silybum marianum L.) on the caspase-3, caspase-9, bax,-2 protein expression and DNA damage in rats with carbon tetrachloride (CCl4)-induced liver damage. 2014.

[27] Zhou, B., et al., Silibinin protects rat cardiac myocyte from isoproterenol-induced DNA damage independent on regulation of cell cycle. Biological and Pharmaceutical Bulletin, 2006. 29(9): p. 1900-1905.

[28] García-Maceira, P. and J. Mateo, Silibinin inhibits hypoxia-inducible factor-1 $\alpha$ and mTOR/p70S6K/4E-BP1 signalling pathway in human cervical and hepatoma cancer cells: implications for anticancer therapy. Oncogene, 2009. 28(3): p. 313-324. https://doi.org/10.1038/onc.2008.398

[29] Kulcanay, I., Lavandula stoechas L. Bitki Ekstre ve Yağının Ames/Salmonella/Mikrozom Test Sistemi ile Mutajenitesinin Araştırllmast, in Fen Bilimleri Enstitüsü. 1998, Osmangazi Üniversitesi

[30] Ayral, N., Lavandula stoechas ssp. stoechas bitkisinin uçucu yağının ve uçucu olmayan organik bileşenlerinin incelenmesi ve biyolojik aktivitelerinin belirlenmesi. Marmara Üniversitesi. Fen Bilimleri Enstitüsü Yüksek Lisans Tezi, İstanbul, Türkiye, 1997.

[31] Magro, A., et al., Efficacy of plant extracts against stored products fungi. Revista Iberoamericana de Micología, 2006. 23(3): p. 176-178. https://doi.org/10.1016/s1130$\underline{1406(06) 70039-0}$ 